Mulyk V, Ananchenko K, Perevoznyk V, Perebyinis V, Soroka V. Characteristics of physical capacities of single combat masters of different age groups. Theory and Methods of Physical education and sports. 2019; 1: 29-35

DOI:10.32652/ tmfvs.2019.1.29-35
Мулик В, Ананченко К, Перевозник В, Перебийніс В, Сорока В Характеристика фрізичних якостей єдиноборців-ветеранів різних вікових груп. Теорія і методика фрізичного виховання і спорту. 2019; 1: 29-35 DOI:10.32652/tmfvs.2019.1.29-35

\title{
ХАРАКТЕРИСТИКА ФІЗИЧНИХ ЯКОСТЕЙ СДИНОБОРЦІВ-ВЕТЕРАНІВ РІЗНИХ ВІКОВИХ ГРУП
}

\author{
В’ячеслав Мулик, Костянтин Ананченко, \\ Володимир Перевозник, Володимир Перебийніс, \\ Владислав Сорока
}

Харківська державна академія фізичної культури, Харків, Україна

\begin{abstract}
Анотація. З віком істотно змінюються фрізичний стан, фрізичні якості та рухові навички людини. Відбуваються значні зміни і в координації рухів: знижується точність їх виконання, сповільнюються темп, рухливість, зменшується швидкість реакції, знижується швидкість освоєння нових рухових дій. Проте, не зважаючи на велике відображення цих аспектів в літературних джерелах, слід відмітити наявність суперечливих думок з питань норм i, особливо, режимів рухової активності, а також регламентації фрізичних навантажень, переважно спрямованих на підтримання рухово-координаційних здібностей спортсменів-ветеранів. Мета. Визначити зміни рівня фрізичних якостей єдиноборців різних вікових груп під впливом тренувальних занять. Методи. Для визначення рівня прояву фрізичних якостей використовували загально-підготовчі і спеціальні вправи єдиноборців, які займалися тричі на тиждень і брали участь у змаганнях відповідно до прийнятих в єдиноборствах вікових груп. Результати тестів взято із протоколів контрольних тестувань на початку змагального періоду як найчастіше застосовуваних під час визначення рівня розвитку фрізичних якостей у єдиноборців і найбільш доступних для виконання спортсменами різного віку. Результати. Проведені дослідження дозволили встановити динаміку прояву фрізичних якостей єдиноборців-ветеранів у різні вікові періоди спорту ветеранів. У результаті дослідження встановлено, що після припинення активних занять спортом поступово знижується рівень фрізичних якостей, проте в досліджуваних вікових періодах він відбувається нерівномірно. Отримані результати свідчать про поступове зниження показників фрізичної підготовленості протягом досліджуваного періоду, що пов'язано в окремих випадках зі збільщенням маси тіла та поступовим згасанням рухового потенціалу спортсменів-ветеранів.
\end{abstract}

Ключові слова: спортсмени-ветерани, фрізичні якості, вікові періоди.

\section{Viacheslav Mulyk, Kostiantyn Ananchenko, Volodymyr Perevoznyk, Volodymyr Perebyinis, Vladyslav Soroka \\ CHARACTERISTICS OF PHYSICAL CAPACITIES OF SINGLE COMBAT MASTERS OF DIFFERENT AGE GROUPS}

\begin{abstract}
Human physical condition, physical qualities and motor skills tend to change significantly with age. There are significant changes in the coordination of movements as well: the accuracy of their execution decreases, the pace and mobility slow down, the reaction speed diminishes, the rate of new motor action development decreases. However, despite large reflection of these aspects in literary sources, it should be noted that there are contradictory opinions on the issues of norms and, especially, the modes of motor activity, as well as the regulation of physical loads, mainly aimed at maintaining the motor coordination abilities of athletes-masters. Objective. To determine changes in the level of physical qualities of single combat athletes of different age groups under the influence of training sessions. Methods. To determine the level of manifestation of physical qualities general preparatory and special exercises performed by single combat athletes were used, who trained three times a week and participated in competitions in accordance with adopted in martial arts age groups. The results of tests were taken from the protocols of control tests at the beginning of the competition period as the most commonly used in determining the level of development of physical qualities in single combat fighters and the most accessible to perform by athletes of different ages. Results. The conducted studies allowed to establish the dynamics of the manifestation of physical qualities of single combat masters in different age periods of veterans' sports. As a result of the study, it was found that after the cessation of active sports practicing, the level of physical qualities is gradually reduced, but in the studied age periods has occured unevenly. The obtained results indicate gradual decrease of physical fitness indices during the period of studies, which is connected in some cases with an increase in body weight and gradual decrease of the motor potential of athletes-masters.
\end{abstract}

Keywords: athletes-masters, physical qualities, age periods.

Вступ. Відомо, що з віком істотно змінюються фізичний стан, фізичні якості та рухові навички людини [15, 16, 19, 20]. Відбуваються значні зміни і в координації рухів: Знижується точ- ність їх виконання, сповільнюються темп, рухливість, зменшується швидкість реакції, знижується швидкість освоєння нових рухових дій $[5,6$, $9,14]$. 
Таблиця 1 - Порівняльна характеристика показників фізичної підготовленості ветеранів-єдиноборців у період активних занять спортом та після них

\begin{tabular}{|l|c|c|c|c|}
\hline \multirow{2}{*}{\multicolumn{1}{|c|}{ Показник }} & \multirow{2}{*}{$\begin{array}{c}\text { в період активних } \\
\text { занять спортом }\end{array}$} & \multicolumn{2}{|c|}{ Після активних занять спортом, роки } \\
\cline { 2 - 5 } & $\bar{X}_{1} \pm \mathrm{m}_{1}$ & $\mathbf{3 1 - 3 4}$ & $\mathbf{3 5 - 4 0}$ & $\mathbf{4 1 - 4 5}$ \\
\cline { 2 - 5 } & $2871,0 \pm 39,33$ & $2733,2 \pm 39,34$ & $2702,1 \pm 37,69$ & $2671,1 \pm 38,16$ \\
\hline Тест Купера, м & $4,14 \pm 0,06$ & $4,44 \pm 0,08$ & $4,53 \pm 0,08$ & $4,59 \pm 0,08$ \\
\hline Біг на 30 м, с & $251,1 \pm 2,77$ & $243,4 \pm 2,70$ & $239,4 \pm 2,72$ & $234,2 \pm 2,71$ \\
\hline Стрибок у довжину з місця, см & $50,2 \pm 0,96$ & $43,9 \pm 0,86$ & $39,4 \pm 0,97$ & $36,1 \pm 0,88$ \\
\hline Стрибок угору з місця, см & $13,20 \pm 0,11$ & $12,77 \pm 0,13$ & $12,50 \pm 0,13$ & $12,01 \pm 0,14$ \\
\hline П'ятиразовий стрибок, м & $28,55 \pm 0,54$ & $30,54 \pm 0,58$ & $31,49 \pm 0,59$ & $32,12 \pm 0,58$ \\
\hline Біг на 200 м, с & $10,11 \pm 0,05$ & $10,30 \pm 0,06$ & $10,58 \pm 0,06$ & $11,18 \pm 0,05$ \\
\hline Човниковий біг 4 х 10 м, с & $23,4 \pm 0,43$ & $22,1 \pm 0,54$ & $19,3 \pm 0,57$ & $16,6 \pm 0,55$ \\
\hline Підтягування на перекладині, разів & $8,8 \pm 0,26$ & $9,4 \pm 0,27$ & $10,8 \pm 0,28$ & $12,4 \pm 0,26$ \\
\hline Час 10 підтягувань на перекладині, с & $35,8 \pm 0,95$ & $38,7 \pm 0,97$ & $40,4 \pm 0,97$ & $42,9 \pm 0,96$ \\
\hline Час виконання 18 кидків, с & & $\bar{X}_{2}$ & $\mathrm{~m}_{3}$ \\
\hline
\end{tabular}

Проте, не зважаючи на велике відображення цих аспектів в літературних джерелах [10, 19], слід відмітити наявність суперечливих думок 3 питань норм i, особливо, режимів рухової активності, а також регламентації фізичних навантажень, переважно спрямованих на підтримання рухово-координаційних здібностей спортсменівветеранів.

У процес виконання довільної рухової дії залучаються не тільки рухові системи організму (м'язи, рухові нерви, що передають імпульси в м'язи від головного і спинного мозку), а й рухові центри мозку. При цьому чутливі системи організму в процесі виконання руху задіяні не менше, ніж рухові [18].

Мета дослідження - визначити зміни рівня фізичних якостей єдиноборців різних вікових груп під впливом тренувальних занять.

Методи дослідження: аналіз науково-методичної літератури, результатів тестів, узятих із протоколів контрольних тестувань на початку змагального періоду як найчастіше застосовуваних під час визначення рівня розвитку фізичних якостей у єдиноборців і доступних для виконання спортсменами різного віку [9].

Результати дослідження та їх обговорення. Останнім часом велика увага приділяється спорту ветеранів, проводяться змагання різного рівня, що вимагає розробки тренувального процесу, який повинен врахувати функціональний стан кожного спортсмена та мотивацію тренувань. На сьогодні існує незначна кількість публікацій [2, 11-13, 21], в яких аналізується зміна показників функціонального стану та рухових якостей відповідно до вікового періоду.

Ученими розглядаються питання визначення біологічного віку, який має зв'язок із роботоздатністю спортсменів-ветеранів [3, 6-8, 12, 16, 17].
Крім цього важливою є профілактика у тренувальному процесі випадків отримання травм, наслідки яких негативно позначаються на здоров’ї спортсменів. Тренувальний процес єдиноборців має свої особливості, пов'язані зі специфікою видів спорту, яка також повинна враховувати вікові періоди при виході із спорту вищих досягнень [1]. Очевидно, що перш ніж здійснювати планування тренувального процесу єдиноборців-ветеранів необхідно визначити динаміку прояву рухових якостей і пов'язаний 3 нею функціональний стан організму. Тому отримані нами дані прояву рухових якостей як загальної, так і спеціальної фізичної підготовки та змін морфофункціональних показників дає можливість індивідуалізувати тренувальний процес єдиноборців-ветеранів різних вікових груп [4].

Для визначення рівня прояву фізичних якостей використовувалися загально-підготовчі і спеціальні вправи єдиноборців, які займалися тричі на тиждень і брали участь у змаганнях відповідно до прийнятих в єдиноборствах вікових груп (31-34; 35-40; 41-45 років). У дослідженні брали участь 12 чоловік.

Порівняльний аналіз рівня показників фізичних якостей спортсменів-ветеранів свідчить про поступове їх зниження (табл. 1).

Результати виконання тесту Купера свідчать про різке скорочення довжини дистанції, що долається за 12 хв в період переходу спортсменів у статус ветеранів $(t=2,47$; $<<0,05)$, тоді як у подальшому зміни між окремими віковими періодами не достовірні ( $>$ 0,05) (табл. 2). Зазначене свідчить, що однотипність тренувальної діяльності (двічі-тричі на тиждень) сприяла стабілізації їхньої фізичної підготовленості.

Аналогічну тенденцію мають i швидкісні та швидкісно-силові якості. Так, результати в бігу 
на 30 м мають суттєве погіршення після 35-40 років та 41-45 років відносно результатів, показаних спортсменами в період активних виступів $(\mathrm{t}=4,82$ та 5,72; р < 0,001) (див. табл. 2).

Швидкісно-силові якості дзюдоїстів-ветеранів, що проявляються у стрибкових тестах, мають більш виражені зміни в стрибку вгору з місця, в якому значні достовірні зміни відбулися у другий $(\mathrm{t}=2,86 ; \mathrm{p}<0,01)$ та третій $(\mathrm{t}=2,52 ; \mathrm{p}<0,05)$ віковий період (табл. 3). У стрибку у довжину 3 місця суттєво погіршилися результати між першим і третім $(\mathrm{t}=2,50 ; \mathrm{p}<0,05)$ та другим і четвертим $(\mathrm{t}=2,40 ; \mathrm{p}<0,05)$ віковими періодами (див. табл. 3).

Результати п'ятиразового стрибка достовірно погіршуються в перший віковий період спорту ветеранів (31-34 роки) ( $\mathrm{t}=2,68$; $\mathrm{p}<0,05)$ та у період з 35-40 до 41-45 років $(\mathrm{t}=2,59 ; \mathrm{p}<0,05)$ (табл. 4).

Тенденція зменшення довжини стрибка у кожному віковому періоді відносно результатів періоду активних занять свідчить про поступове згасання швидкісно-силового м'язового потенціалу єдиноборців-ветеранів.

Найбільш трудомістким видом прояву швидкісно-силових якостей у єдиноборців є багаторазові стрибкові вправи, до яких належить п'ятиразовий стрибок. Отримані результати мають достовірні зміни відразу після припинення активних занять спортом $(\mathrm{t}=2,68$; $\mathrm{p}<0,05)$, а потім відбувається їх стабілізація з деякою тенденцією до зниження $(t=0,96 ; p>0,05)$ на третьому етапі та суттєвим зниженням на наступному етапі спорту ветеранів $(t=2,59 ; \mathrm{p}<0,05)$. Зниження результатів можна пояснити як збільшенням маси тіла, що виникає за рахунок різкого скорочення часу, відведеного на тренування, так і відсутністю в заняттях єдиноборців-ветеранів спеціальних стрибкових вправ.

Результати у бігу в анаеробно-аеробному режимі (біг на 200 м) суттєво погіршуються одразу після виходу із спорту вищих досягнень $(\mathrm{t}=4,40$; $\mathrm{p}<0,001)$, а потім стабілізуються $(\mathrm{p}>0,05)$ (див. табл. 4). Показники у човниковому бігу погіршуються кожного вікового періоду $(\mathrm{t}=2,44 ; 3,59$; 2,31; р < 0,05-0,01) (табл. 5).

Спеціальне тестування (час виконання 18 кидків), проведене після активних занять спортом у перший період спорту ветеранів, показало зниження результатів на 2,9 кидка $(\mathrm{t}=2,13$; p < 0,05), у подальшому результати стабілізувалися $(\mathrm{p}>0,05)$ (див. табл. 5).

Силові показники м'язів верхніх кінцівок також змінювалися 3 кожним віковим періодом. Так, у підтягуванні на перекладині з кожним періодом зменшується кількість разів $\left(\mathrm{t}_{1,2}=2,13\right.$; $\left.\mathrm{t}_{2,3}=3,59 ; \mathrm{t}_{3,4}=5,62 ; \mathrm{p}<0,05-0,001\right)$, а час 10 підтягувань суттєво збільшується, порівняно 3 третім і четвертим віковими періодами $\left(\mathrm{t}_{3,4}=2,08\right.$; p > 0,05) (табл. 6). Крім цього, у єдиноборців, старших 30 років, у багатьох тестах збільшилося середньоквадратичне відхилення ( $\delta)$, що свідчить про різний ступінь зміни результатів у окремих спортсменів. Очевидно, що погіршення виконання силових вправ пов'язане зі збільшенням маси тіла та стану м'язових волокон верхніх кінцівок, а отримані показники фізичних якостей свідчать про поступове згасання рухового потенціалу спортсменів-ветеранів.

Проведений кореляційний аналіз взаємозв'язку показників функціонального стану єдиноборцівветеранів різних вікових періодів свідчить, що іс-

Таблиця 2 - Матриця достовірності різниці показників тесту Купера та бігу на 30 м єдиноборців-ветеранів у період активних занять та в період виходу зі спорту вищих досягнень

\begin{tabular}{|c|c|c|c|}
\hline \multirow{2}{*}{$\begin{array}{c}\text { Вік, } \\
\text { років }\end{array}$} & \multicolumn{3}{|c|}{ Показники у віковому періоді } \\
\hline & до $\mathbf{3 0}$ років & $\mathbf{3 1 - 3 4}$ роки & $\mathbf{3 5 - 4 0 ~ р о к і в ~}$ \\
\hline $31-34$ & $t=2,47$ & & \\
& $(p<005)$ & & \\
& $t=1,77$ & & \\
& $(p>0,05)$ & & \\
& $t=4,82$ & $t=0,98$ & \\
\hline $35-40$ & $(p<0,001)$ & $(p>0,05)$ & \\
& $t=2,73$ & $t=0,36$ & \\
& $(p<0,05)$ & $(p>0,05)$ & \\
\hline \multirow{4}{*}{$41-45$} & $t=5,72$ & $t=1,13$ & $t=0,58$ \\
& $(p<0,001)$ & $(p>0,05)$ & $(p>0,05)$ \\
\hline & $t=4,50$ & $t=1,36$ & $t=0,55$ \\
& $(p<0,001)$ & $(p>0,05)$ & $(p>0,05)$ \\
\hline
\end{tabular}

Примітки: у чисельнику - показники тесту Купера; у знаменнику - показники бігу на 30 м

Таблиця 3 - Матриця достовірності різниці показників у стрибку вгору та у довжину з місця єдиноборців-ветеранів у період активних занять та в період виходу зі спорту вищих досягнень

\begin{tabular}{|c|c|c|c|}
\hline \multirow{2}{*}{$\begin{array}{l}\text { Вік, } \\
\text { років }\end{array}$} & \multicolumn{3}{|c|}{ Показники у віковому періоді } \\
\hline & до 30 років & 31-34 роки & 35-40 років \\
\hline \multirow[t]{2}{*}{$31-34$} & $\begin{array}{c}t=2,86 \\
(p<0,01)\end{array}$ & & \\
\hline & $\begin{array}{c}t=2,04 \\
(p>0,05)\end{array}$ & & \\
\hline \multirow[t]{2}{*}{$35-40$} & $\begin{array}{c}t=5,04 \\
(p<0,001)\end{array}$ & $\begin{array}{c}t=0,80 \\
(p>0,05)\end{array}$ & \\
\hline & $\begin{array}{c}t=2,50 \\
(p<0,05)\end{array}$ & $\begin{array}{c}t=1,13 \\
(p>0,05)\end{array}$ & \\
\hline \multirow[t]{2}{*}{$41-45$} & $\begin{aligned} t & =10,85 \\
(p & <0,001)\end{aligned}$ & $\begin{array}{c}t=6,34 \\
(p<0,001)\end{array}$ & $\begin{array}{c}t=2,52 \\
(p<0,05)\end{array}$ \\
\hline & $\begin{array}{c}t=4,37 \\
(p<0,001)\end{array}$ & $\begin{array}{c}t=2,40 \\
(p<0,05)\end{array}$ & $\begin{array}{c}t=1,35 \\
(p>0,05)\end{array}$ \\
\hline
\end{tabular}

Примітки: у чисельнику - показники стрибка вгору 3 місця; у знаменнику - показники стрибка у довжину з місця 
Таблиця 4 - Матриця достовірності різниці показників п'ятиразового стрибка та бігу на 200 м єдиноборцівветеранів у період активних занять та в період виходу зі спорту вищих досягнень

\begin{tabular}{|c|c|c|c|}
\hline \multirow{2}{*}{$\begin{array}{l}\text { Вік, } \\
\text { років }\end{array}$} & \multicolumn{3}{|c|}{ Показники у віковому періоді } \\
\hline & до 30 років & 31-34 роки & 35-40 років \\
\hline \multirow[t]{2}{*}{$31-34$} & $\begin{array}{c}t=2,68 \\
(p<0,05)\end{array}$ & & \\
\hline & $\begin{array}{c}t=4,40 \\
(p<0,001)\end{array}$ & & \\
\hline \multirow[t]{2}{*}{$35-40$} & $\begin{array}{c}t=3,54 \\
(p<0,01)\end{array}$ & $\begin{array}{c}t=0,96 \\
(p>0,05)\end{array}$ & \\
\hline & $\begin{array}{c}t=5,80 \\
(p<0,001)\end{array}$ & $\begin{array}{c}t=1,44 \\
(p>0,05)\end{array}$ & \\
\hline \multirow[t]{2}{*}{$41-45$} & $\begin{array}{c}t=6,61 \\
(p<0,001)\end{array}$ & $\begin{array}{c}t=4,00 \\
(p<0,001)\end{array}$ & $\begin{array}{c}t=2,59 \\
(p<0,05)\end{array}$ \\
\hline & $\begin{array}{c}t=6,38 \\
(p<0,001)\end{array}$ & $\begin{array}{c}t=4,12 \\
(p<0,001)\end{array}$ & $\begin{array}{c}t=1,01 \\
(p>0,05)\end{array}$ \\
\hline
\end{tabular}

Примітки: у чисельнику - показники п'ятиразового стрибка; у знаменнику - показники бігу на 200 м

Таблиця 5 - Матриця достовірності різниці показників човникового бігу $4 \times 10$ м та часу виконання 18 кидків єдиноборців-ветеранів у період активних занять та в період виходу зі спорту вищих досягнень

\begin{tabular}{|c|c|c|c|}
\hline \multirow{2}{*}{$\begin{array}{l}\text { Вік, } \\
\text { років }\end{array}$} & \multicolumn{3}{|c|}{ Показники у віковому періоді } \\
\hline & до 30 років & 31-34 роки & 35-40 років \\
\hline \multirow[t]{2}{*}{$31-34$} & $\begin{array}{c}t=2,44 \\
(p<0,05)\end{array}$ & & \\
\hline & $\begin{array}{c}t=2,13 \\
(p<0,05)\end{array}$ & & \\
\hline \multirow[t]{2}{*}{$35-40$} & $\begin{array}{c}t=4,03 \\
(p<0,001)\end{array}$ & $\begin{array}{c}t=3,59 \\
(p<0,01)\end{array}$ & \\
\hline & $\begin{array}{c}t=3,38 \\
(p<0,01)\end{array}$ & $\begin{array}{c}t=1,25 \\
(p>0,05)\end{array}$ & \\
\hline \multirow[t]{2}{*}{$41-45$} & $\begin{array}{c}t=5,88 \\
(p<0,001)\end{array}$ & $\begin{array}{c}t=4,12 \\
(p<0,001)\end{array}$ & $\begin{array}{c}t=2,31 \\
(p<0,05)\end{array}$ \\
\hline & $\begin{array}{c}t=4,59 \\
(p<0,001)\end{array}$ & $\begin{array}{c}t=3,21 \\
(p<0,01)\end{array}$ & $\begin{array}{c}t=1,86 \\
(p>0,05)\end{array}$ \\
\hline
\end{tabular}

Примітки: у чисельнику - показники човникового бігу $4 \times 10$ м; у знаменнику - показники часу виконання 18 кидків

Таблиця 6 - Матриця достовірності різниці показників часу 10 підтягувань на перекладині єдиноборців-ветеранів у період активних занять та в період виходу зі спорту вищих досягнень

\begin{tabular}{|c|c|c|c|}
\hline \multirow{2}{*}{$\begin{array}{l}\text { Вік, } \\
\text { років }\end{array}$} & \multicolumn{3}{|c|}{ Показники у віковому періоді } \\
\hline & до 30 років & 31-34 роки & 35-40 років \\
\hline $31-34$ & $\begin{array}{c}t=1,58 \\
(p>0,05)\end{array}$ & & \\
\hline $35-40$ & $\begin{array}{c}t=5,26 \\
(p<0,001)\end{array}$ & $\begin{array}{c}t=1,40 \\
(p>0,05)\end{array}$ & \\
\hline $41-45$ & $\begin{array}{c}t=5,95 \\
(p<0,001)\end{array}$ & $\begin{array}{c}t=6,17 \\
(p<0,001)\end{array}$ & $\begin{array}{c}t=2,08 \\
(p>0,05)\end{array}$ \\
\hline
\end{tabular}

нує кореляційна залежність окремих показників в різні вікові періоди. Так, відзначено тісну кореляційну залежність діастолічного артеріального тиску і маси тіла єдиноборців 35-40 років $(\mathrm{r}=0,60)$ та 41-45 років $(\mathrm{r}=0,53)$. Це може свідчити про те, що з віком збільшення маси тіла тягне за собою підвищення викиду крові 3 порожнини серця за рахунок збільшення кількості скорочень, тобто частоти пульсу.

Крім цього існує кореляційна залежність між артеріальним систолічним тиском і частотою серцевих скорочень у єдиноборців 35-40 років ( $\mathrm{r}=$ $=0,59)$ і 41-45 років $(r=0,61)$. Цей взаємозв'язок виправданий, оскільки заснований на скорочувальній функції серцевого м'яза. Також відмічено кореляційну залежність між складовими артеріального систолічного і діастолічного тиску в трьох вікових періодах спорту ветеранів ( $\mathrm{r}=0,50$; $\mathrm{r}=0,56 ; \mathrm{r}=0,57)$.

Як бачимо, протягом дослідження вікових періодів змінюються показники функціонального стану організму єдиноборців-ветеранів, а також існує кореляційна залежність між окремими їх показниками, що відображають діяльність серцевосудинної системи.

Результати кореляційного аналізу дзюдоїстівветеранів 31-34 років показують середній негативний взаємозв'язок результатів бігу на 30 м і стрибка у довжину 3 місця $(\mathrm{r}=-0,63)$ і п'ятиразового стрибка $(\mathrm{r}=-0,54)$; бігу на 200 м і тесту Купеpa $(\mathrm{r}=-0,57)$, п’ятиразового стрибка $(\mathrm{r}=-0,53)$ та човникового бігу $(r=0,63)$. Так само виявлено середній кореляційний зв'язок між стрибковими вправами: п'ятиразовим стрибком і стрибком у довжину з місця $(\mathrm{r}=0,68)$ і стрибком угору з місця $(\mathrm{r}=0,54)$.

Також при зміні рівня прояву фізичних якостей у перший період спорту ветеранів існує кореляційний взаємозв'язок між стрибковими вправами $(r=0,68 ; r=0,56 ; r=0,54)$, а також тестами, пов'язаними з бігом (тест Купера - біг на 200 м, r $=-0,57$ ) та бігом і стрибками (біг на 30 м - стрибок у довжину з місця $\mathrm{r}=-0,63$; біг на 200 м - п'ятиразовий стрибок $\mathrm{r}=-0,53)$. Виявлено кореляційну залежність між масою тіла єдиноборців і стрибковими тестами $(\mathrm{r}=-0,59 ; \mathrm{r}=$ $=-0,75 ; \mathrm{r}=-0,61)$ та підтягуванням на перекладині $(\mathrm{r}=0,78)$ та часу 10 підтягувань $(\mathrm{r}=0,72)$, результати яких значно зменшилися у зв'язку зі збільшенням маси тіла. Зі збільшенням цього показника збільшився і час подолання дистанції 200 м $(r=0,56)$.

Крім цього відмічено середній негативний кореляційний взаємозв'язок показників систолічного артеріального тиску і результатів тесту Купеpa $(r=-0,74)$ і бігу на 30 м $(r=-0,56)$. Показники бігу на 200 м також мають середню кореляційну залежність від діастолічного артеріального тиску $(r=0,60)$. 
Анаеробна метаболічна ємність серцевого м'яза корелює 3 тестами, які передбачають прояв швидкісно-силових якостей: біг на 30 м ( $\mathrm{r}=$ $=-0,72)$, стрибок у довжину 3 місця $(\mathrm{r}=0,56)$, п'ятиразовий стрибок $(r=0,68)$, біг на 200 м $(\mathrm{r}=-0,65)$. Аеробна метаболічна ємність має середню кореляційну залежність із результатами тесту Купера $(r=-0,62)$.

Зіставлення тестів, що відображають рівень прояву фізичних якостей і функціонального стану організму єдиноборців-ветеранів вказує на наявний кореляційний взаємозв'язок між частотою серцевих скорочень і бігом на 30 м $(\mathrm{r}=-0,55)$ i 200 м $(\mathrm{r}=-0,51)$; артеріальним систолічним тиском і бігом на 30 м $(r=0,63)$ і п'ятиразовим стрибком $(\mathrm{r}=0,59)$; діастолічним артеріальним тиском і бігом на 200 м $(\mathrm{r}=-0,60)$; анаеробною метаболічною ємністю серцевого м'яза і бігом на 30 м $(\mathrm{r}=-0,72)$ і 200 м $(\mathrm{r}=-0,65)$, а також стрибком у довжину $(\mathrm{r}=0,56)$ і вгору $(\mathrm{r}=0,65)$ з місця; аеробною метаболічною ємністю і результатами тесту Купера $(r=0,62)$.

У наступному віковому періоді (35-40 років) є така сама, як і в попередньому, тенденція кореляційної залежності між окремими показниками фізичної підготовленості, а також даними тестів функціонального стану організму єдиноборцівветеранів. Зниження результатів відбулося в усіх стрибкових тестах, що виражалося в тісному кореляційному взаємозв'язку між стрибками у довжину i вгору з місця $(\mathrm{r}=0,81)$, стрибком угору і п'ятиразовим стрибком $(\mathrm{r}=0,75)$, стрибком у довжину і п'ятиразовим стрибком $(\mathrm{r}=0,55)$. Також відмічено середню негативну кореляційну залежність між бігом на 200 м і бігом у тесті Купера $(\mathrm{r}=-0,59)$, бігом на 200 м і п'ятиразовим стрибком $(r=-0,53)$, бігом на 30 м і п'ятиразовим стрибком $(\mathrm{r}=-0,62)$ і човниковим бігом $4 \times 10$ м $(\mathrm{r}=0,63)$.

Негативну кореляційну залежність встановлено між частотою серцевих скорочень і бігом на 30 м $(r=-0,63)$ та 200 м $(r=-0,58)$. Середню кореляційну залежність мають також показники систолічного артеріального тиску і тестів 3 проявом швидкісно-силових якостей - бігу на 30 м $(\mathrm{r}=0,63)$ і п'ятиразового стрибка $(\mathrm{r}=0,61)$. Негативну кореляцію мають діастолічний артеріальний тиск з біговими тестами - тестом Купера $(\mathrm{r}=-0,55)$ і бігом на 200 м $(\mathrm{r}=-0,72)$, а також анаеробна метаболічна ємність серцевого м'яза 3 бігом на 30 м і 200 м $(\mathrm{r}=-0,55 ; \mathrm{r}=-0,64)$. Аеробна метаболічна ємність серця має тісний взаємозв'язок з тестом Купера $(\mathrm{r}=0,64)$. Виявлено, що результати педагогічного тестування в усі вікові періоди корелюють з масою тіла ( $\mathrm{r}=0,56-$ 0,78) спортсменів-ветеранів, яка підвищується, особливо відразу після закінчення активної тренувальної діяльності, що позначається на зниженні результатів тестування фізичних якостей.
У наступному віковому періоді (41-45 років, а також у 46-50, 51-55 та 56-60 років) проходить стабілізація прояву рухових якостей відносно морфофункціональних показників.

Кореляційна залежність показників морфофункціонального стану і тестів, що відображають рівень розвитку фізичних якостей, повною мірою відповідає і для єдиноборців подальших вікових груп. Так, існує середній рівень корекції виконання тестів розвитку рухових якостей: тесту Купеpa i бігу на 200 м $(\mathrm{r}=0,59)$; бігу на 30 м і стрибка у довжину з місця $(\mathrm{r}=-0,63)$ та п'ятиразового стрибка $(\mathrm{r}=-0,54)$; стрибка у довжину 3 місця i п'ятиразового стрибка $(\mathrm{r}=0,55)$ та стрибка вгору 3 місця $(\mathrm{r}=0,54)$; п'ятиразового стрибка і бігу на 200 м $(\mathrm{r}=-0,53)$ та човникового бігу $(\mathrm{r}=-0,47)$; бігу на 200 м і човникового бігу $(r=0,48)$; підтягування на перекладині і часу 10 підтягувань на перекладині $(\mathrm{r}=-0,78)$.

Також виявлено, що існуе кореляційний взаємозв'язок між рівнем прояву рухових якостей та морфофункціональними показниками: тест Купеpa й аеробна метаболічна ємність $(r=0,52)$; біг на 30 м і частота серцевих скорочень $(\mathrm{r}=-0,53)$, артеріальний систолічний тиск $(\mathrm{r}=-0,56)$, артеріальний діастолічний тиск $(\mathrm{r}=0,53)$ та анаеробна метаболічна ємність $(\mathrm{r}=-0,72)$; стрибок у довжину з місця і маса тіла $(\mathrm{r}=0,59)$ та анаеробна метаболічна ємність $(\mathrm{r}=-0,56)$; п'ятиразовий стрибок і маса тіла $(\mathrm{r}=-0,75)$; біг на 200 м і маса тіла $(r=-0,56)$, частота серцевих скорочень $(\mathrm{r}=0,50)$, артеріальний систолічний тиск і артеріальний діастолічний тиск $(\mathrm{r}=0,60 ; 0,65)$; човниковий біг і частота серцевих скорочень $(\mathrm{r}=-0,56)$, артеріальний систолічний тиск $(\mathrm{r}=0,56)$ та анаеробна метаболічна ємність $(\mathrm{r}=0,53)$; підтягування на перекладині і маса тіла $(\mathrm{r}=-0,72)$, анаеробна метаболічна ємність $(\mathrm{r}=0,52)$ та аеробна метаболічна ємність $(\mathrm{r}=0,54)$; використання 18 кидків і маса тіла $(\mathrm{r}=-0,68)$, частота серцевих скорочень $(\mathrm{r}=0,52)$, анаеробна метаболічна ємність $(\mathrm{r}=0,56)$ та аеробна метаболічна ємність $(\mathrm{r}=0,53)$.

\section{Висновки:}

1. Результати тестування спортсменів різних вікових групах свідчать, що після припинення активних занять спортом поступово знижується рівень фізичних якостей, проте у досліджуваних вікових періодах він відбувається нерівномірно.

2. У віковій групі 30-34 роки більшою мірою знижуються результати, пов'язані 3 проявом швидкісно-силових якостей $(\mathrm{p}<0,05)$ і спеціальної швидкісної витривалості ( $<<0,01)$, що більшою мірою пояснюється припиненням активної тренувальної діяльності і різким збільшенням маси тіла спортсменів. Проведений кореляційний аналіз також показує тісний взаємозв'язок маси тіла і показників стрибка у довжину і вгору з місця і п'ятиразового стрибка, а також бігу на 200 м $(\mathrm{r}=-0,59 ; \mathrm{r}=-0,60 ; \mathrm{r}=-0,75 ; \mathrm{r}=-0,56)$. 
Виявлено зниження результатів у віковому періоді 41-45 років порівняно з попереднім у стрибку вгору з місця $(\mathrm{p}<0,05)$, тоді як в інших показниках вони достовірно незначущі ( $p>0,05)$. Встановлено кореляційну залежність динаміки зміни результатів стрибкових тестів, тестів швидкісно-силового характеру і показників серцево-судинної системи.

3. У подальшому результати тестування стабілізуються і у більшості показників не мають сут- тєвої різниці відносно попередніх, за винятком результатів у віковому періоді 41-45 років порівняно 3 попереднім у стрибку вгору 3 місця $(\mathrm{p}<0,05)$.

Перспективи подальших досліджень передбачають визначення функціонального стану єдиноборців-ветеранів різних вікових груп під впливом тренувального процесу.

Конфлікт інтересів. Автори заявляють, що відсутній будь-який конфлікт інтересів.

\section{Література}

1. Ананченко КВ. Техніко-тактична підготовка дзюдоїстів високого класу на основі аналізу модельних характеристик [авторефрерат]. - Харків, 2006. 19 с.

2. Вовканич ЛС, Бергтраум ДІ. Фізіологічні основи фрізичного виховання і спорту : навч. посібник для перепідготовки спеціалістів ОКР «бакалавр» : у 2 ч. Львів : ЛДУФК; 2013. Ч. 2. 196 с.

3. Войтенко ВП. Факторы смертности и продолжительность жизни: монография. Киев: Здоров'я; 1987.144 с.

4. Годик МА. Педагогические основы нормирования и контроля соревновательных и тренировочных нагрузок [авторефрерат]. Москва; 1982. 37 с.

5. Камаєв ОІ, Паєвський ВВ, Шевченко ОО. Поточний контроль показників фрізичної підготовленості курсантів військового закладу різних курсів навчання. Слобожанський науково-спортивний вісник. 2013; 2(35):18-21.

6. Коробейніков Г, Адирхаєв С, Медвичук К, Мазмаян К, Житовоз М. Біологічний вік та фрізична активність людини. Теорія і методика фрізичного виховання і спорту. 2007; 1: 60-63.

7. Мулик ВВ. Система багаторічного спортивного удосконалення в ускладнених умовах поєднання основних сторін підготовленості спортсменів (на матеріалі лижного спорту) [автореферат]. Київ; 2002. 40 с.

8. Мулик ВВ. Анализ системы подготовки ветеранов в лыжных видах спорта циклического характера. Основи побудови тренувального процесу в циклічних видах спорту. Харків; 2016: 18-22.

9. Мунтян ВС. Оптимізація спеціальної підготовки в рукопашному бою з урахуванням індивідуальних особливостей спортсменів [авторефрерат]. Харків, 2006. 20 с.

10. Олешко ВГ, Пуцов АИ, Пуцов СА, Коробейников ГВ, Медвидчук КВ, Коняева ЛД. Функциональный возраст и темп старения спортсменов-ветеранов. Проблемы старения и долголетия. 2006; 15(2): 112-118.

11. Пакулін СЛ, Перебийніс ВБ. Удосконалення тренувального процесу та техніко-тактичної підготовки дзюдоїстівветеранів. Науковий часопис Національного педагогічного університету імені М. П. Драгоманова. 2017; 2(83)17: 8589.

12. Перебийніс ВБ. Особливості спортивної підготовки дзюдоїстів-ветеранів. Слобожанський науково-спортивний вісник. 2013; 4(37): 56-59.

13. Перебийніс ВБ, Пакулін СЛ. Оцінка біологічного віку та «кількості здоров'я» дзюдоїстів-ветеранів на етапі виходу із спорту вищих досягнень. Слобожанський науково-спортивний вісник, 2016; 6(56): 74-78.

14. Перевозник ВІ. Особливості побудови тренувального процесу фуубболістів-ветеранів [авторефрерат]. Харків; 2004. $20 \mathrm{c}$.

15. Платонов ВН. Система подготовки спортсменов в олимпийском спорте. Общая теория и ее практические приложения : учебник [для тренеров] : в 2 кн. Киев: Олимпийская лит.; 2015. 1. 680 с.

16. Платонов ВН. Двигательные качества и фризическая подготовка спортсменов. Киев: Олимпийская лит.; 2017. $656 \mathrm{c}$.

17. Решетюк АЛ, Поляков ОА, Коробейніков ГВ. Визначення функціонального віку та темпів старіння людини. Київ: МОЗ України; 1996. 8 с.

18. Ровний АС. Система сенсорного контролю точних рухів спортсменів. Физическое воспитание студентов творческих специальностей. 2000; 3. 38-41.

19. Ровный АС. Пути мобилизации физиологических резервов в системе управления движениями спортсмена. Слобожанський науково-спортивний вісник. 2008; 2: С. 129-132.

20. Фединяк Н, Мицкан Б. Біологічний вік і темп старіння людей різних вікових груп. Молодіжний науковий вісник Східноєвропейського національного університету імені Лесі Українки. 2013; 12: 45-50.

21. Rovniy A, Mulyk K, Perebeynos V, Ananchenko K, Pasko V, Perevoznyk V, Aleksieiev A, Dzhym V. (2018). Optimization of judoist training process at a stage of gradual decline of sporting achievements. Journal of Physical Education and Sport (JPES), 18(4), Art 367, pp. 2447-2453. DOI:10.7752/jpes.2018.04367.

\section{Literature}

1. Ananchenko KV. Technico-tactical preparation of skilled judokas on the basis of model characteristics analysis. Kharkiv, 2006. 19 p.

2. Vovkanych LS, Bergtraum DI. Physiological bases of physical education and sport : teaching guide for retraining of "Bachelor" specialists OKR : in 2 p. Lviv : LSUPC; 2013. Part 2. 196 p. 
3. Voytenko VP. Factors of mortality and longevity: monograph. Kiev: Zdorovia; 1987.144 p.

4. Godik MA. Pedagogical bases of norming and controlling competitive and training loads [author's abstract]. Moscow; 1982. $37 \mathrm{p}$.

5. Kamaiev OI, Paievskyi VV, Shevchenko OO. Current control for physical fitness indices of cadets. Slobozhanskyi naukovo-sportyvnyi visnyk. 2013; 2(35):18-21.

6. Korobeynikov H, Adyrkhaiev S, Medvychuk K, Mazmaian K, Zhyvotoz M. Human biological age and physical activity. Teoriia i metodyka fizvykhovannia i sportu. 2007; 1: 60-63.

7. Mulyk VV. System of long-term athletic improvement under complicated conditions of combining the main aspects of athlete fitness (as exemplified by ski sport) [author's abstract]. Kyiv; 2002. 40 p.

8. Mulik VV. Analysis of masters preparation systema in ski sports events of cyclic character. Kharkiv; 2016: 18-22.

9. Muntian VS. Special preparation optimization in hand-to-hand combat with account for athletes' individual peculiarities [author's abstract]. Kharkiv, 2006. 20 p.

10. Oleshko VG, Putsov AI, Putsov SA, Korobeynikov GV, Medvichuk KV, Konyayeva LD. Functional age and aging rate of athletes-masters. Issues of aging and longevity. 2006; 15(2): 112-118.

11. Pakulin SL, Perebiynis VB. Improving training process and technico-tactical preparation of judokas-masters. Naukovyi chasopys Natsionalnoho universytetu imeni M. P. Drahomanova. 2017; 2(83)17: 85-89.

12. Perebiynis VB. Sports preparation peculiarities of judokas-masters. Slobozhanskyi naukovo-sportyvnyi visnyk. 2013; 4(37): 56-59.

13. Perebiynis VB, Pakulin SL. Estimating biological age and "health quantity" of judokas-masters at the stage of elite sport withdrawal. Slobozhanskyi naukovo-sportyvnyi visnyk, 2016; 6(56): 74-78.

14. Perevoznyk VI. Features of training process design for masters footballers: [author's abstract]. Kharkiv; 2004.20 p.

15. Platonov VN. System of athletes' preparation in the Olympic sport. General theory and its practical applications : textbook [for coaches] : in 2 books. Kiev: Olimpiyskaya literatura; 2015. 1. 680 p.

16. Platonov VN. Motor qualities and physical preparation of athletes. Kiev: Olimpiyskaya literatura; $2017.656 \mathrm{c}$.

17. Reshetiuk AL, Poliakov OA, Korobeynikov HV. Determining human functional age and aging rates. Kyiv: MOZ Ukrainy; 1996. 8 p.

18. Rovnyi AS. System of sensory control for precise motions of athletes. Fizicheskoye vospitaniye studentov tvorcheskikh spetsialnostey. 2000; 3. 38-41.

19. Rovny AS. Ways of mobilizing physiological reserves in the system of athlete motion management. Slobozhanskyi naukovo-sportyvnyi visnyk. 2008; 2: P. 129-132.

20. Fedyniak N, Mytskan B. Biological age and aging rate of persons of different age groups. Molodizhnyi naukovyi visnyk Skhidnoievropeyskoho universytetu imeni Lesi Ukrainky. 2013; 12: 45-50.

21. Rovniy A, Mulyk K, Perebeynos V, Ananchenko K, Pasko V, Perevoznyk V, Aleksieiev A, Dzhym V. (2018). Optimization of judoist training process at a stage of gradual decline of sporting achievements. Journal of Physical Education and Sport (JPES), 18(4), Art 367, pp. 2447-2453. DOI:10.7752/jpes.2018.04367

Надійшла 06.11.2018

\section{Інформація про авторів}

Мулик В'ячеслав,

https://orcid.org/0000-0002-4441-1253;

kateryna.mulyk@gmail.com;

Ананченко Костянтин,

https://orcid.org/0000-0001-5915-7262,

2015akv@gmail.com;

Перевозник Володимир,

https://orcid.org/0000-0001-6798-1497;

Перебийніс Володимир,

Сорока Владислав,

Харківська державна академія фізичної культури;

61058, м. Харків, вул. Клочківська, 99.
Information about the authors

Mulyk Viacheslav,

https://orcid.org/0000-0002-4441-1253; kateryna.mulyk@gmail.com;

Ananchenko Kostiantyn, https://orcid.org/0000-0001-5915-7262,

2015akv@gmail.com;

Perevoznyk Volodymyr, https://orcid.org/0000-0001-6798-1497;

Perebeynos Volodymyr,
Soroka Vladislav,

Soroka Vladislav, Kharkiv State Academy of Physical Culture;
61058, m. Kharkiv, vul. Klochkovskaya 99 